\title{
Intra-Gulf Cooperation Council : Saudi Arabia Effect
}

\author{
Nasser Al-Mawali \\ Sultan Qaboos University, Sultanate of Oman, Oman
}

\begin{abstract}
The main thrust of this study is to investigate the extent to which Saudi Arabia's economic growth acts as an engine of growth for the Gulf Co-operation Council region. The estimation results of Gulf Cooperation Council for the last three decades suggest that the growth of Saudi Arabia, along with the growth of United Arab Emirates and Bahrain, is positive and statistically significant in explaining the overall growth of the Gulf Cooperation Council region. The main policy implication of these findings is that the positive intra-economic growth of these countries should serve as further motivation for the intra-regional integration of the Gulf Cooperation Council.
\end{abstract}

JEL Classification: F02, F13, F42, F53

Keywords: Economic Growth, GCC, Economic Integration

* Corresponding Author: Nasser Al-Mawali; College of Economics and Political Science, Sultan Qaboos University, Sultanate of Oman; P.O Box 20, PC 123, Alkhod, Oman; Tel:+968 24141848, Fax: +968 24414043, E-mail: almawali@, squ.edu.om. 


\section{Introduction}

The Gulf Cooperation Council (GCC) is comprised of six member countries: Bahrain, Kuwait, Oman, Qatar, Saudi Arabia, and the United Arab Emirates (UAE). These countries are closely comparable in terms of ethnicity, religion, historical experience, and political systems. However, they differ with regard to their economic and geographical sizes, with Saudi Arabia being the largest in both of these aspects. Figure 1 shows that Saudi Arabia contributed $46 \%$ to the total GDP of the GCC region in 2013, and it is the highest contributor to the region's GDP. Therefore, there is a common view among economists that Saudi Arabia is an engine of the GCC growth, in the sense that Saudi Arabia's and the GCC's outputs are closely correlated. The movement of Saudi Arabia's economic growth is believed to influence the growth of other GCC countries.

The view that Saudi Arabia influences the economic growth of the other GCC countries seems plausible because Saudi Arabia accounts for 55\% of GCC oil reserves, over 50\% of GCC's GDP, and 75\% of the total GCC population (Mason 2014). Furthermore, Saudi Arabia ranks 19th in the world in terms of nominal GDP growth and it is the sole Arab country in the Group of Twenty (G20) nations, an exclusive club of the world's top economies. The combination of its size and the fact that it borders every other GCC member state makes Saudi Arabia a natural leader of the GCC organization, which also has its headquarters in Riyadh (Mason 2014).

The economic growth of Saudi Arabia may get transmitted to the economic growth of the rest of the GCC countries through a number of channels such as trade, investments, and financial linkages. Moreover, its size, political and religious statuses, and economic activities may influence business and consumer confidence in the other GCC countries. Today, potential spillover effects among the GCC states have become easily attainable after some progress toward economic integration among the GCC starting with a Free Trade Area (FTA) in 1983 and moving to a Customs Union in 2003 and a Common Market in 2008; furthermore, the plans for a monetary union are already in place. More details on GCC economic integrations are presented in Section II.

While the view that the growth of Saudi Arabia has a possible impact on the growth of other GCC states seems to be intuitive, there has yet to be some research on how much the Saudi Arabia's growth matters for the other GCC countries. Given this gap in the literature, the main objective of this study is to empirically quantify the extent to which Saudi Arabia is acting as an engine of growth to the rest of the GCC countries, 
using panel data from the last three decades.

The study employs the fixed effects estimation techniques in the context of standard growth models. It will assess only the long-term aggregate impact of Saudi economic growth on the other GCC countries for the last three decades. Investigating alternative channels and ways of how Saudi economic growth gets transmitted to the rest of the GCC countries is left for future research.

The organization of this paper proceeds as follows: Section II provides an overview of GCC economy, followed by a brief review of the relevant literature in Section III. The data and estimation method are detailed in Section IV. Section V presents the empirical results and discussion. The concluding remarks are presented in the final section of the paper.

\section{Figure 1. The share of GCC country}

(in millions of US dollars, year 2013)

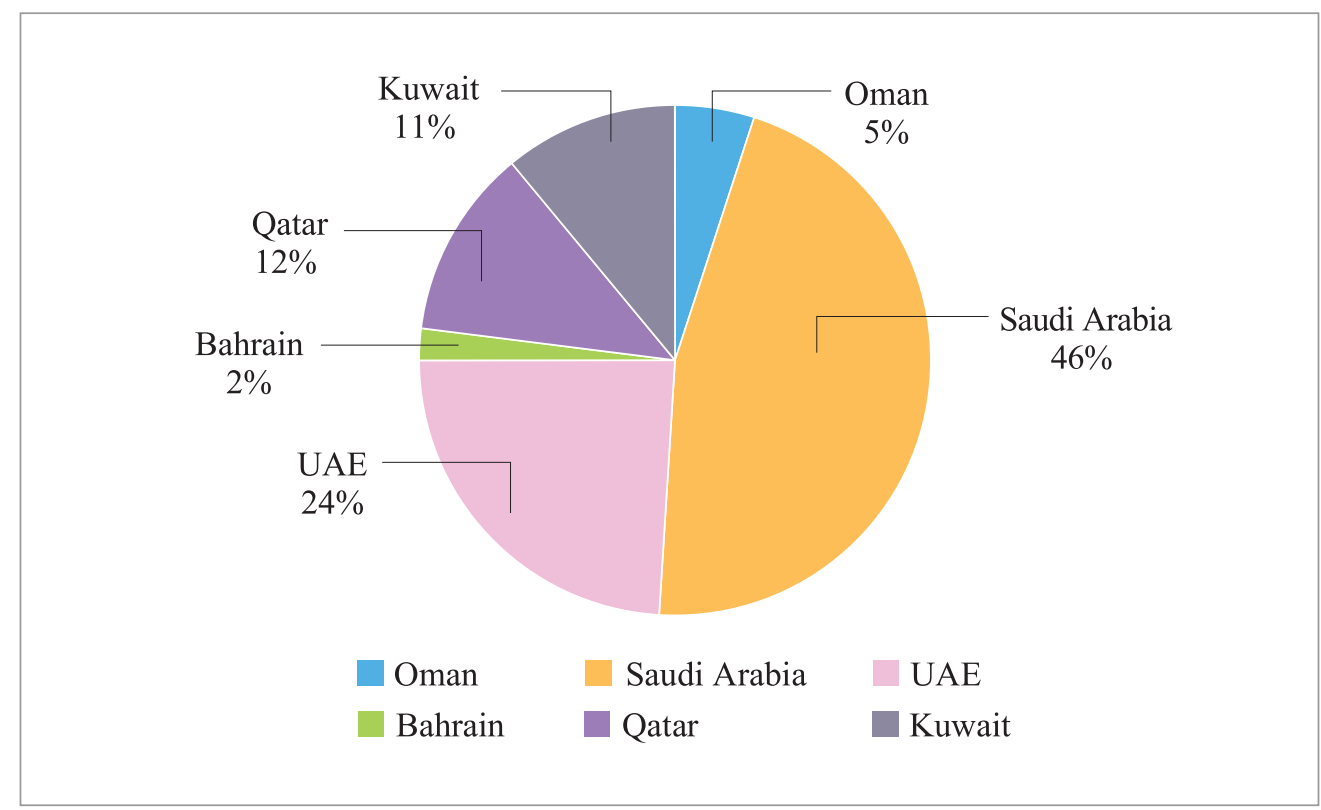

(Source) Author's own construction, data from World Bank (2014). 


\section{GCC Economic Overview}

The GCC was founded on the basis of its members' special relations and shared commonalities such as sharing similar social, cultural, political, and economic characteristics. The overall aim of the Gulf Cooperation Council region (GCC) is to achieve coordination, cooperation, and integration in all fields (GCC Charter 1981). The GCC members have set out to coordinate their policies and generate integration with each other starting with regional FTA in 2008 with the aim to reach an agreement to establish a monetary union. Since the establishment of GCC in 1981, the member states have undergone a striking economic and social transformation.

This section aims to shed some light on the common GCC structural characteristics and also to provide some analysis with regard to the GCC economic integration and the spillover effects which facilitate the intra-GCC economic growth.

\section{A. GCC structural characteristics}

The GCC member states share several commonalities in terms of their culture, language, and geographical location; however, their economies are different. Saudi Arabia is the largest economy in terms of its GDP and population, but GDP per capita is the highest in Qatar and the UAE, and the lowest in Saudi Arabia and Oman (refer to Table 1 below and Table A in the Appendix).

Table 1 reveals that the total GDP of the six member states when it was first established in 1981 was only 260 billion US dollars, whereas it exceeded 1,443 billion US dollars in 2013. Throughout 1981 and 2013, the GDP per capita for the GCC countries as a whole increased by about $70 \%$. Despite differences in sizes, there is also an important common feature of the GCC economies: their fiscal and export revenues highly depend on hydrocarbons, i.e., oil and natural gas, and their macroeconomic performance is highly correlated to the fluctuations in global oil prices. According to a study by Al Masah capital (2013), oil dominates the GCC region's exports accounting for nearly $70 \%$ of all merchandise exports; furthermore, oil production and export constitute around $80 \%$ of export earnings and government revenues in most GCC countries. Kuwait's oil and gas resources account for 53\% of GDP, 93\% of government revenues, and 94\% of export earnings. The situation in Saudi Arabia and Qatar is similar. 
Saudi Arabia's oil and gas resources account for 50\% of GDP, 83\% of government revenues, and 90\% of export earnings, while Qatar's account for 56\% of GDP, $60 \%$ of government revenues, and 80\% of export earnings (Al Masah capital 2013).

Today, the GCC region accounts for more than one-fifth of world oil production and it owns about $40 \%$ of world oil reserves and about $23 \%$ of world natural gas reserves (BP 2014).

The overall economic growth of GCC is faster than that of most emerging economies including Russia and Brazil (Global Economy Watch 2013). Further, it is expected that the GCC countries will continue to be global leaders in the oil business, together producing nearly $25 \%$ of crude and controlling $40 \%$ of proven reserves (BP 2014).

The latest report by the Economist Intelligence Unit (2014) on GCC trade and investment flows stress that the GCC members are increasingly important in the world economy not only because of their massive oil and gas reserves, but also because of the way that the countries are positioning themselves as important hubs. Figure B in the Appendix reveals that about $85 \%$ of GCC imports and exports are conducted with the rest of the world mainly with Asia and the West. Furthermore, comparing trade openness of GCC member states in 1981 to that of 2013, Table 1 shows that there is significant improvement of GCC integration to the rest of world as measured by the merchandize trade as percentage of GDP. The table also illustrates some key economic indicators of GCC countries for the year 1981, when the GCC was first established, and thirty two years later of the year 2013 . 
Table 1. Key GCC indicators

(1981 \& 2013)

\begin{tabular}{|c|c|c|c|c|c|c|}
\hline & Bahrain & Kuwait & Oman & Qatar & $\begin{array}{c}\text { Saudi } \\
\text { Arabia }\end{array}$ & UAE \\
\hline \multicolumn{7}{|l|}{ 1981: year of GCC establishment } \\
\hline Population (million) & 0.36 & 1.45 & 1.25 & 0.25 & 10.19 & 1.10 \\
\hline GDP (Current US\$ billion) & 3.47 & 25.06 & 7.26 & 7.83 & 183.94 & 32.92 \\
\hline GDP per capita (Constant 2000 US\$) & 10,452 & 15,561 & 5,007 &. & 15,782 & 44,186 \\
\hline GDP growth (annual\%) & -5.32 & -19.03 & 17.05 & & 4.69 & 2.84 \\
\hline \multicolumn{7}{|l|}{ Shares of GDP } \\
\hline Agriculture & 1.01 & 0.34 & 2.48 & & 1.01 & 0.84 \\
\hline Manufacturing & 57.80 & 68.69 & 67.13 & & 70.89 & 72.69 \\
\hline Services & 41.18 & 30.96 & 30.40 & & 28.10 & 26.48 \\
\hline Merchandize trade $\%$ of GDP & 244 & 92 & 98 & 83 & 84 & 97 \\
\hline \multicolumn{7}{|l|}{2013} \\
\hline Population (million) & 1.33 & 3.33 & $\begin{array}{r}3.63 \\
79.65\end{array}$ & 2.16 & 28.82 & 9.34 \\
\hline GDP (Current US\$ billion) & 32.89 & 175.83 & & 203.23 & 748.44 & 203.23 \\
\hline GDP per capita (Constant 2000 US\$) & 17.50 & & & 59.89 & 18.06 & 25.14 \\
\hline GDP growth (annual\%) & 5.33 & 6.32 & & 5.32 & 3.95 & 5.19 \\
\hline \multicolumn{7}{|l|}{ Shares of GDP } \\
\hline Agriculture & 1.8 & 0.35 & 0.65 & 0.093 & 1.2 & 0.65 \\
\hline Manufacturing & 10.6 & 6.7 & & 9.9 & 10 & 8.5 \\
\hline Services & & 26.3 & 31.3 & 30.2 & 37.5 & 40.3 \\
\hline Merchandize trade $\%$ of GDP & 176 & 98.10 & 99 & 97 & 82.4 & 180 \\
\hline
\end{tabular}

(Source) World Bank. World Development Indicators (2015), where the data is not available the closest year of available data are used. 


\section{B. Economic integration and spillover effects}

The GCC was established with the objective of coordination and integration in a wide range of areas. During the first two decades of the GCC establishment the emphasis was on cooperation and coordination related to a number of social, economic, and political issues, but the emphasis have now shifted towards more economic integration in the last few years. The progression of GCC's economic integration has followed the four sequential initiatives: Free Trade Areas (FTAs), customs unions, common markets, and monetary union. By following these four phases, the GCC countries aim at establishing an European Union (EU)-style economic bloc.

In 1983, the GCC launched its FTA, which helped to reduce trade restrictions between member countries and which helped trade flows among GCC member states. In fact, the intra-GCC trade has now grown nearly forty-fold since its establishment and has reached more than 90 billion US dollars in 2013 (Seetharaman 2014). The intraGCC trade made up about $8 \%$ of the GCC total trade in 2014. It seems low; however, it is argued that the small volume of GCC intra-trade observed is usually attributed to the similarity of the economic structure of the GCC member countries, as well as their lack of industrial diversification (Havrylyshyn and Kusnel 1997).

The GCC did not progress to the next step of economic integration until 2003, when it initiated a customs union whereby all remaining restrictions among member countries on movement of goods were removed. The GCC also unified its external tariff against non-members in the same year. Moving beyond the trade sector, another milestone was achieved in 2008 when the member countries launched the Gulf common market to ensure greater mobility of capital and labour within the region. The common market was based on the principle of equal treatment of all GCC citizens regarding economic activities in GCC countries.

The last phase of economic integration is the establishment of the monetary union. The GCC has plans to launch a common currency in 2010 and to create a GCC central bank. However, there have also been some unanticipated setbacks to achieving the monetary union. For example, in October 2006, Oman announced that it would not join the union by 2010, and in May 2007 Kuwait also declared that it was moving from the dollar peg to an undisclosed currency basket, although it reaffirmed its commitment to join the union. UAE has also announced that it will not participate in the initial launch of the currency due to the disagreement over the location of the GCC Central Bank. The remaining agenda of establishing the monetary union is certainly challenging and as a 
result, achieving a single GCC currency appears increasingly difficult.

Therefore, the above mentioned phases of GCC economic integration do facilitate the spillover effects from one GCC state to another. Furthermore, the financial markets and monetary policy actions of the GCC economies are found to be significantly linked together in the long run (Darrat and Al-Shamsi 2005). Real exchange rates in this bloc are closely related and share the same stochastic trend, which implies the readiness of the countries for a currency union (Laabas and Limam 2002). Hence, the intra-GCC economic growth is likely to get transmitted from one GCC country, i.e., Saudi Arabia, to other countries through the capital markets and product markets.

The infrastructure development is part of the GCC states' broader strategy to diversify away from hydrocarbons, transform themselves into knowledge economies, and ensure long-term growth. The GCC electricity grid interconnection is a classic example of the GCC integration wherein the project has provided benefits to all member states by increasing efficiencies in the power sector and reducing investment requirements into new electricity generation capacity. The GCC Dolphin pipeline, which transports natural gas from Qatar to the UAE and on to Oman is an example of how cross-border initiatives can create value for all GCC stakeholders. The GCC-wide railway network to connect the GCC, linking Kuwait to Muscat through Saudi Arabia, Bahrain, Qatar, and the UAE, is another example of GCC investments in GCC infrastructure. These projects have been pursued on account of their positive impact on the GCC trade and the freedom of movement of citizens and expats, which will all be reflected in the intra-GCC economic growth.

\section{GCC breakeven oil prices}

In general, most of the GCC economies have made some progress on diversifying their economies away from oil production; however, there is still a high level of dependency on oil income in all GCC countries. The dependency of public finances is an indicator of the budget's vulnerability to oil price trends. The budget breakeven price of GCC countries has risen sharply in recent years and the situation varies widely among countries. The Regional Economic Outlook report by International Monetary Fund (IMF) (2014) projected that Bahrain and Oman would have the highest break-even oil prices in the GCC in 2015 at US dollars $116 \mathrm{pb}^{1}$ and US dollars $107 \mathrm{pb}$, respectively (refer to Figure 2 below). At the other end of the spectrum, Kuwait is expected to have the lowest 
break-even oil price at US dollars 53pb in 2015, which reflects the relatively low level of budget spending as it is the least diversified in terms of sources of budget revenues. Saudi Arabia's break-even oil price this year is around US dollars 90pb (refer to Figure 2 below).

For years, GCC economies have been moved by huge spending splurges from governments. Such expenditure reached an apex after the global financial crisis in 2009 and the Arab Spring in 2011 as several GCC states beefed up spending on infrastructure and wages and unemployment benefits; for example, Saudi Arabia's spending as percentage of GDP rose from 40\% in 2003 to $65 \%$ last year. Because of the fall in oil prices and the rise in the break-even prices, the IMF expected that half of the GCC Saudi Arabia, Oman, and Bahrain, would post budget deficits in the year 2015. The surpluses of the other half, UAE, Qatar, and Kuwait, are expected to be increasingly squeezed and the economic growth of GCC member countries will be reflected in the intra-GCC economic growth.

Figure 2. GCC breakeven oil prices

(2010 2015)

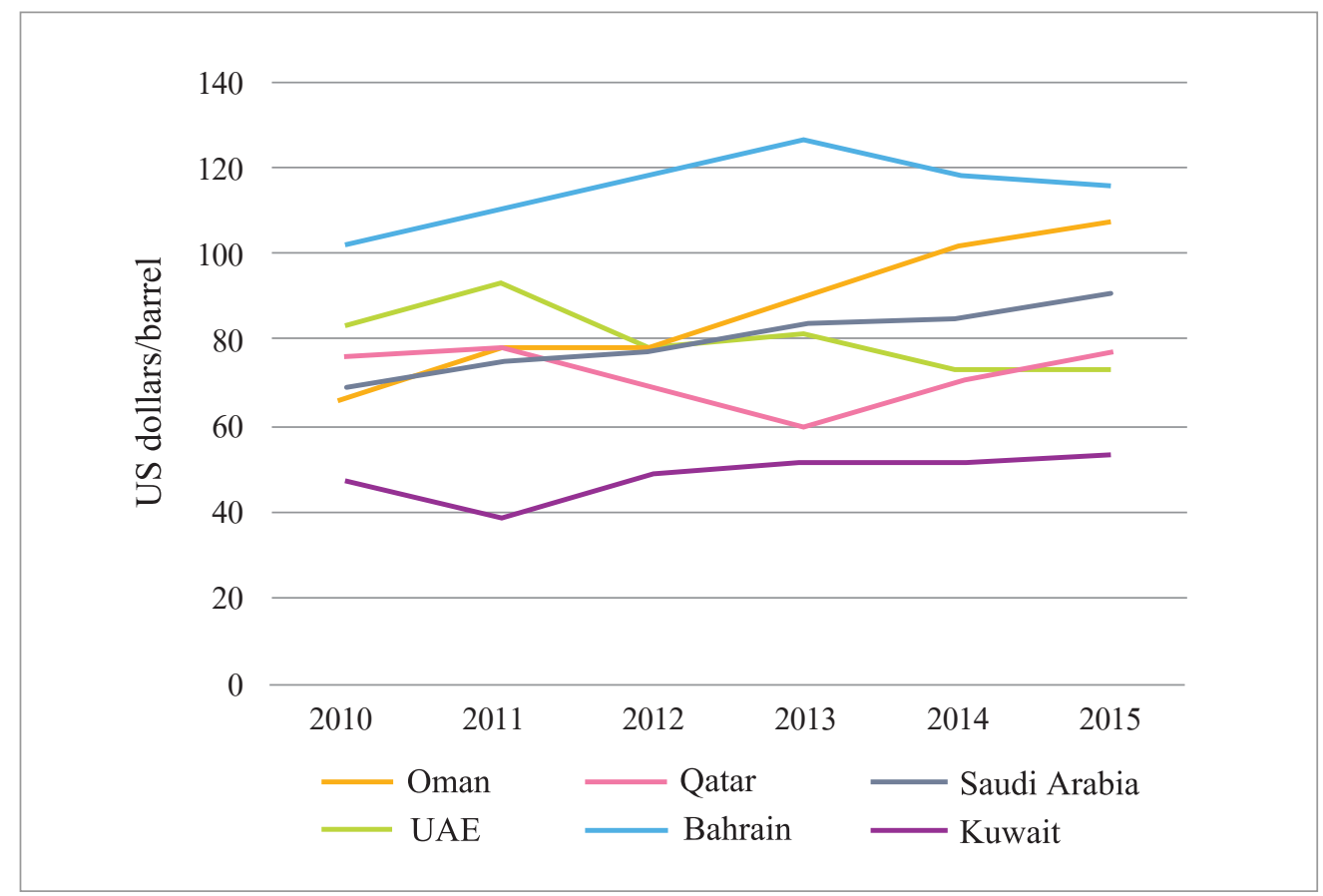

(Source) Author's own construction, data from IMF, Regional Economic Outlook, 2014. Data for 2015 are projections. 


\section{Literature}

A considerable literature exists exploring the various channels of economic growth spillover, such as the spillover of economic growth that comes through Foreign Direct Investment (FDI), international trade, technology transfer, and other channels (Gorg and Greenaway 2004, Chun-Yu et al. 2013). However, there has been very little research that focuses on measuring the aggregate impact of one country's economic growth on the growth of other countries within an economic bloc. Only three studies are identified in the literature that are exclusively focused on quantifying the extent of the impact of one country's growth on the growth of one or more other countries: Arora and Vamvakidis (2004, 2005, and 2010).

Arora and Vamvakidis (2004) quantified the extent to which US growth is an engine of the world economy and found that there is a significant positive impact; the impact is as great as one-for-one for the period studied (1980 1998). In another study, Arora and Vamvakidis (2005) measured the extent to which South African economic growth is an engine of growth in Sub-Saharan Africa, using panel data estimations for 47 African countries, and concluding that South African growth has a substantial positive impact on growth in the rest of Sub-Saharan African. Their recent research was on China's role in the world economy in the short and long term (Arora and Vamvakidis 2010). The results of this study show that the spillover effects of China's growth have increased in recent decades, and the long-term spillover effects are also significant.

\section{Methodology and Data}

\section{A. Baseline model}

The empirical model used in this study is the same as the one used by Arora and Vamvakidis (Arora and Vamvakidis 2004, 2005, and 2010) which is standard in the growth literature:

$$
Y_{i t}=\alpha_{i}+\beta x_{i t}+U_{i t}
$$


where $i$ denotes a country and $t$ a time period; $\mathrm{Y}$ is the dependent variable, which is the average per capita real GDP growth rate; $\alpha_{i}$ is the matrix of constant terms for each country $i ; \beta$ is a matrix parameter to be estimated and $X_{i}$ is the matrix of independent variables that are standard variables in growth regressions; and $\mathrm{U}$ is the error term.

Considering the standard growth decompositions of Equation (1), the baseline model is as follows:

$$
\begin{gathered}
\mathrm{Y}_{i t}=\beta_{i t}+\beta_{1} \bar{Y}_{i t}+\beta_{2} I N F_{i t}+\beta_{3} P O P_{i t}+\beta_{4} H U M_{i t}+\beta_{5} O P E N_{i t} \\
+\beta_{6} I N V_{i t}+\beta_{7} G_{i t}+u_{i t}+v_{i}+\varepsilon_{i t}
\end{gathered}
$$

In this relationship, $\mathrm{Y}$ indicates the five-year average per capita real GDP growth rate. The standard explanatory growth determinants are as follows: $\bar{Y}$ shows the initial level of real per capita GDP at the beginning of each five-year period; INF is the inflation rate measured by the annual percentage of consumer prices; $P O P$ indicates population growth rate measured by annual population growth; HUM is a measure of human capital measured by secondary-school enrolment as a percentage of gross population. OPEN is trade openness measured by total trade as a percentage of GDP; INV is investment in physical capital measured by gross capital formation as a percentage of GDP; Gov is the size of the government measured by government final consumption expenditure as a percentage of GDP, $\varepsilon$ is the error term, and $u_{\zeta}$ and $v$ are country- and time-specific effects, respectively.

In addition, and most importantly in terms of estimating the impact of economic growth in Saudi Arabia on the other GCC countries, $\mathrm{X}_{\mathrm{i}}$ includes the growth rate of real per capita GDP in Saudi Arabia as an independent variable (Specification 2). Finally, in order to test whether the results are driven by any global trends, $X_{i}$ also includes a variable to measure world real per capita GDP growth.

All data are from the World Bank's World Development Indicators (2014). The growth models are estimated for the last three decades from 1980 to 2012, including all six GCC countries. The study employs multi-year averages and focuses on longrun rather than short-run effects; this is to avoid the possibility of any business cycle fluctuations that may cause a short-term volatility in the time series of the GCC countries. In the first specification (Specification 1), standard determinants of growth for the whole GCC region are estimated. In the second specification (Specification 2), Saudi Arabia is excluded from the sample and its real growth rate per capita is treated as one of the independent variables. In the third specification, real growth rate per capita 
for each GCC country is entered as an independent variable along with other growth determinants, while its own GDP per capita growth is excluded from the dependent variable. Each observation is a five-year average except for initial GDP per capita, which takes the value of the first year for each five-year period. The study employs fixed effects estimation based on the results of the Hausman test and F-test that reject the hypothesis that the individual effects are uncorrelated with other regressors.

\section{B. Endogeneity issue}

A standard problem in empirical work of economic growth is the potential of endogeneity of Right-Hand-Side (RHS) variables. If any of variables are correlated with the error term then that variable is considered econometrically endogenous and therefore OLS may yield biased and inconsistent coefficient estimates (Wooldridge 2013).

The literature identified three sources of endogeneity: omitted variables, simultaneity and measurement error (Wooldridge 2013). While the three factors may contribute potentially to the endogeneity bias, we believe that the issue of omitted variables may be of a concern in this study because of the availability of wide variety of factors which may contribute to the economic growth of GCC. The present study dealt with issue of potential endogeneity in two different ways: firstly, dependent variable $(Y)$ is calculated based on the five-year average which helps to reduce any possible effects of endogeneity. Secondly, the present study employs fixed effect model, using fixed effects model is one of the existing techniques to address the issue of endogeneity (Wooldridge 2013) especially in the case of omitted variables bias, using fixed effects technique to deal with endogeneity has been of use in many empirical works such as Nanda and Sorensen (2010) and Fairli (2013).

\section{Empirical Results}

The overall results of the fixed effects estimation of the baseline model (Specification 1) that included all GCC countries conform to prior expectations and can be interpreted as offering empirical validation for the theoretical explanatory variables that have been 
suggested in the economic growth literature as outlined by the first specification in Table 2 .

The signs and/or significance of explanatory variables are generally as expected, except for those of physical investment (INV), which is negative but not significant; otherwise, the initial GDP per capita $(\bar{Y})$ is negative and significant, confirming the convergence hypothesis. Inflation rate and population have a negative sign, as expected, and both are statistically significant; trade openness prompts economic growth with an expected positive sign; secondary-school enrolment, which is used as a proxy for investment in human capital, is also significant with an expected positive sign. The effect of government expenditure on economic growth in the GCC region is negative but not statistically significant. Indeed, the empirical evidence on whether increasing government expenditure promotes economic growth is not yet conclusive (Alshahrani and Alsadiq 2014). Finally, the growth of world GDP per capita is surprisingly negative, but not statically significant, which suggests that the global shocks are not important to GCC growth. This warrants further investigation.

The main thrust of the second specification, as shown in Table 2, is to test the impact of Saudi Arabia's growth on the growth of the GCC region. The empirical results show that the growth rate of Saudi Arabia impacts positively on the determinants of the GCC economic growth and is statistically significant. A one percentage point increase in Saudi Arabian growth leads to an increase of almost 8 percentage points in GCC economic growth. The results, then, confirm the prior expectation that the positive economic growth of Saudi Arabia does matter for the growth of the other GCC countries. The remaining determinants of economic growth did not alter much in terms of statistical significance compared with previous specifications, except for the physical investment variable which turned out to be statistically significant.

In 2011, an extraordinary wave of popular protest swept the Arab world including some of the GCC states. Arab Spring has led to social unrest and an economic downturn (Khandelwa and Roitman 2013). In GCC, there was a peaceful protest in Oman. Omani protesters demanded salary increases, creation of more jobs, and a reduction in corruption. However, the effects of the Arab Spring in GCC was more severe in Bahrain when violence highly raged in the capital Manama which was latter suppressed by government forces after a three-month state of emergency. A dummy variable, Arab Spring, takes the value of 1 if GCC countries experienced violence and sustained unrest as a result of the Arab Spring and 0, otherwise. The inclusion of the Arab Spring dummy allows this paper to assess intra-GCC growth in the political context.

The empirical results of the impact of the Arab Spring on GCC countries are positive 
as shown in the third column of Table 2. However, they are statistically insignificant, which is against the expectation. The statistical insignificance of the dummy variable of the Arab Spring may be due to the fact that the protests did not last long in GCC; furthermore, it was mainly in Bahrain, which is the smallest country in the GCC in terms of economic and physical size.

Table 2. Estimation results

\begin{tabular}{|c|c|c|}
\hline & Specification (1) & Specification (2) \\
\hline $\begin{array}{l}\text { Explanatory } \\
\text { Variables }\end{array}$ & $\begin{array}{l}\text { The dependent variable is average } \\
\text { per capita real GDP growth rate for } \\
\text { all GCC countries (full sample) }\end{array}$ & $\begin{array}{l}\text { The dependent variable is average per } \\
\text { capita real GDP growth rate for all } \\
\text { GCC countries except Saudi Arabia }\end{array}$ \\
\hline Constant & $\begin{array}{l}1.8333 \\
(1.05)\end{array}$ & $\begin{array}{l}2.547 \\
(1.18)\end{array}$ \\
\hline$\overline{\boldsymbol{Y}}_{i t}$ & $\begin{array}{c}-0.352 * * * \\
(-22.24)\end{array}$ & $\begin{array}{c}-0.268 * * * \\
(-12.68)\end{array}$ \\
\hline$I N F_{i t}$ & $\begin{array}{c}-0.009^{*} \\
(-1.7)\end{array}$ & $\begin{array}{c}-0.235^{* *} \\
(-2.50)\end{array}$ \\
\hline$P{ }_{i t}$ & $\begin{array}{c}-0.076^{*} \\
(-2.11)\end{array}$ & $\begin{array}{c}-0.015^{*} \\
(-2.65)\end{array}$ \\
\hline$H U M_{i t}$ & $\begin{array}{c}0.0113^{* * *} \\
(2.63)\end{array}$ & $\begin{array}{c}0.092 * * * \\
(3.76)\end{array}$ \\
\hline OPEN $_{i t}$ & $\begin{array}{c}0.0095^{* *} \\
(1.91)\end{array}$ & $\begin{array}{c}0.0267^{* *} \\
(1.23)\end{array}$ \\
\hline$I N V_{i t}$ & $\begin{array}{c}-0.0411 \\
(-0.97)\end{array}$ & $\begin{array}{c}0.0324^{*} \\
(1.745)\end{array}$ \\
\hline$G O V_{i t}$ & $\begin{array}{c}-0.0624 \\
(-1.41)\end{array}$ & $\begin{array}{l}-0.034 \\
(-1.45)\end{array}$ \\
\hline $\begin{array}{l}\text { Growth of world } \\
\text { GDP per capita }\end{array}$ & $\begin{array}{c}-0.0006 \\
(-0.28)\end{array}$ & $\begin{array}{l}-.0034 \\
(-0.289)\end{array}$ \\
\hline $\begin{array}{l}\text { Growth of Saudi } \\
\text { Arabia's GDP } \\
\text { per capita }\end{array}$ & - & $\begin{array}{c}0.0793 * * \\
(2.74)\end{array}$ \\
\hline $\begin{array}{l}\text { Arab Spring } \\
\text { (Dummy variable) }\end{array}$ & - & - \\
\hline$R$-square & 0.74 & 0.67 \\
\hline$F$-Statistics & 88.62 & 38.62 \\
\hline
\end{tabular}

(Notes) $t$-statistics for the fixed effects model are given in parentheses; $*, * *, * * *$ indicate that the given variable is statistically significant up to the $10 \%, 5 \%$, and $1 \%$ level of significance, respectively; otherwise, the variable is statistically insignificant. The reported R-square is overall R-square. 
The results of the second specification have created an interest in this paper to test the individual impact of growth for all other GCCs in the overall GCC region. Table 3 shows the individual growth spillovers of each of the GCC countries on the overall GCC region. Interestingly, $\mathrm{UAE}$ and Bahrain appeared to also have a statistically positive impact on the growth of the rest of the GCC region, as shown in Table 3.

The positive results of the effects of the Bahrain economy on the economic growth of GCC may reflect the fact that Bahrain, according to the 2015 Index of Economic Freedom, has the freest economy in GCC and its economy relies on the GCC economy, especially Saudi Arabia. Bahrain's trade with the GCC has been steadily increasing (refer to Figure B in the Appendix). Furthermore, a study by Sahib and Kari (2012) confirms that Bahrain's trade intensity index of its intra-GCC trade is negative which implies that Bahrain relies on the other GCC countries to obtain its commodity needs (Sahib and Kari 2012).

UAE also plays a vital role in the GCC economy mainly through trade, while UAE plays the role as a regional re-importer and re-exporter. Because of the Customs Union, UAE-GCC trade has surged by 405\% from 2003 to 2012, the volume of trade reached 195.8 billion $\mathrm{AED}^{2}$ in imports, 97.1 billion AED in exports, and 166.1 billion AED in reexports in 2003 2012. The increasing trade flows between UAE and the rest of GCC are reflected in Figure $\mathrm{C}$ in the Appendix.

The fact that three of the GCC countries, namely Saudi Arabia, UAE, and Bahrain, are important for the overall real growth of the GCC region suggests that this phenomenon should literally be labelled intra-GCC economic growth. This may motivate GCC countries to speed up the process of economic integration, which is currently stalled at the stage of the formation and implementation of the monetary union.

Furthermore, the presented estimates of the study are robust to the effects of regional shocks, changes in model specifications, and sample period. To ensure the robustness of the estimates, several diagnostic tests on the chosen model in this study are performed and treated accordingly, including: testing for heteroskedasticity using the Breusch-Pagan and Cook-Weisberg tests; multicollinearity test using correlation matrix and Variance Inflation Factor (VIF); normality test using skewness/kurtosis test and normality graphs; model specification test using link specification test; and omitted variables test using Ramsey RESET test.

${ }^{2} \mathrm{AED}=$ United Arab Emirates Dirham 
Table 3. Growth impact of each GCC on the region

\begin{tabular}{|l|c|c|c|c|}
\hline Country & $\begin{array}{c}\text { Estimate of the } \\
\text { Growth Impact }\end{array}$ & $\boldsymbol{t}$-statistic & $\boldsymbol{F}$-statistic & $\boldsymbol{R}$-square \\
\hline Oman & -0.003 & -0.17 & 100 & 0.85 \\
\hline Kuwait & 0.330 & 0.58 & 69.28 & 0.78 \\
\hline Qatar & 0.0784 & 0.91 & 74.18 & 0.77 \\
\hline UAE & $0.057^{* *}$ & 3.01 & 130.12 & 0.85 \\
\hline Bahrain & $0.168^{* *}$ & 2.53 & 40.72 & 0.72 \\
\hline
\end{tabular}

(Notes) (i) The employed model specification is similar to Specification (2).

(ii) * denote statistically significant at $10 \%$, ** denote statistically significant at $5 \%$, *** denote statistically significant at $1 \%$.

(iii) The dependent variable is different each time; it is the growth of real per capita GDP for all GCC countries, excluding the country that has its growth in real per capita GDP on the right hand side of the equation.

\section{Concluding Remarks}

The study has provided a quantitative assessment of the extent to which Saudi Arabia's economic growth matters for the Gulf Cooperation Council (GCC) region. The empirical results based on fixed effects panel estimation suggest that Saudi's economic growth is an engine of growth for the GCC region, which confirms the prior, unquantified, and commonly held view that Saudi Arabia, being the largest country in the GCC region, does drive the economic growth of the GCC region. Furthermore, the study also found that the real economic growth in UAE and Bahrain has a positive spillover to the rest of the GCC region. Positive spillovers of economic growth of the three GCC countries to the rest of the countries in the region might be labelled intraGCC economic growth; this has an important policy implication. The findings of the study should motivate the GCC region to accelerate the process of GCC economic integration, which has been slow so far: the process started in 1983 and recently became stalled at the stage of implementation of the monetary union.

Future research should look at the mechanisms and channels through which the 
economic growth gets transmitted from one country to the rest of the GCC and should also look at its implications on intra-regional integration.

Received 16 November 2014, Revised 21 May 2015, Accepted 21 July 2015

\section{References}

Akilou Amadou. "Is There a Causal Relation between Trade Openness and Economic Growth in the WAEMU Countries?.” International Journal of Economics and Finance 5 (2013):151-156.

Al Masah Capital Management Limited. Report on Managing Oil Wealth, Dubai, United Arab Emirates, 2013.

Alshahrani, Saad and Alsadiq Ali. "Economic Growth and Government Spending in Saudi Arabia: an Empirical Investigation.” IMF Working Paper WP/14/13, 2013.

Arora, Vivek and Vamvakidis Athansasios. "China’s Economic Growth: International Spillovers", IMF Working Paper WP/10/165, 2010.

Arora, Vivek, and Vamvakidis Athansasios. "The Implications of South African Economic Growth for the Rest of Africa." South African Journal of Economics, 73 (2005): 229-242.

Arora, Vivek, and Vamvakidis Athansasios. "The Impact of U.S. Economic Growth on the Rest of the World: How Much Does It Matter?." Journal of Economic Integration, 19 (2004): 1-18.

British Petroleum. "Statistical Review of World Energy." June 10, 2013. Accessible http://www.bp.com/content/dam/bp/pdf/Energy-economics/statistical-review-2014/ BP-statistical-review-of-world-energy-2014-full-report.pd.

Chun-Yu, H.; Wei Wang; and Jihai, Yu. "Growth spillover through trade: A spatial dynamic panel data approach". Economic Letters 120 (2013):450-453.

Darrat, Ali., and Al Shamsi Fatima. "On the Path of Integration in the Gulf Region". 
Applied Economics 37 (2005):1055-1062.

Economist Intelligence Unit. "Report on GCC Trade and Investment Flows". United Kingdom, London, 2014.

Fairlier, Robert. "Entrepreneurship, Economic Condition, and the Great Recession". Journal of Economics and Management Strategy 22 (2013): 207-231.

Global Economy Watch. " Business as Usual is Changing: our Predictions for 2013”, January 2013. Accessible http://www.pwc.co.uk/economic-services/global-economywatch/january-2013-summary.jht.

Gorg, Holger, and Greenaway David. "Much ado about nothing? Do domestic firms really benefit from foreign direct investment?". World Bank Research Observer 19 (2004):171-197.

Khandelwa, Padamja and Roitman Agusin. "The Economics of Political Transitions: Implications for the Arab Spring". IMF Working Paper, WP/13/69, 2013.

Laabas, Belkacem and Limam, Imad. "Are GCC Countries Ready for Currency Union?,". Arab Planning Institute Working Paper No 0203, 2002.

Havrylyshyn, Oil and Kusnel Peter. "Intra-industry trade for Arab countries: an indicator of potential competitiveness". IMF Working Paper, WP/97/47,1997.

Mason Robert. "The Omani Pursuit of a Large Peninsula Shield Force: A Case Study of a Small State's Search for Security”. British Journal of Middle Eastern Studies, June (2014):355-367.

Nanda, Ramana and Sorensen Jesper. "Workplace peers and entrepreneurship". Management Science 56 (2010):116-1126.

Sahib, Ahme , and Kari Fatima. “Analysis of Intensity of Intra-Regional Trade in GCC Countries, 1998-2008”. International Journal of Trade, Economics \& Finance, 3(2012): 223-226.

Wooldridge, Jeffrey. Introductory Econometrics: A modern Approach. SouthWestern Cengage learning, 2013.

World Bank, World Development Indicators, World Bank, Washington, DC, 2014.

World Bank, World Development Indicators, World Bank, Washington, DC,2015. 


\section{Appendices}

Table A. GCC selected economic indicators

\begin{tabular}{|c|c|c|c|}
\hline & $\begin{array}{l}1981 \sim 1990 \\
\text { average }\end{array}$ & $\begin{array}{l}\text { 1991 2000 } \\
\text { average }\end{array}$ & $\begin{array}{l}\text { 2001 2010 } \\
\text { average }\end{array}$ \\
\hline Nominal GDP (in billions of US dollars) & 184.3 & 274.2 & 721.1 \\
\hline $\begin{array}{l}\text { Real GDP growth } \\
\text { (PPP GDP weighted average) }\end{array}$ & 0.6 & 4.2 & 5.0 \\
\hline $\begin{array}{l}\text { Non-oil real GDP growth } \\
\text { (PPP GDP weighted average) }\end{array}$ & & 4.6 & 6.6 \\
\hline GDP per capita (US dollars) & 10206.0 & 18092.0 & 20756.0 \\
\hline Oil production (mbpd) & 11.0 & 13.5 & 15.0 \\
\hline Oil exports (mbpd) & 8.2 & 10.7 & 14.6 \\
\hline CPI (period average, $\%$ change) & 1.2 & 1.6 & 3.5 \\
\hline Fiscal balance (in billions of US dollars) & -7.8 & 0.9 & 89.7 \\
\hline $\begin{array}{l}\text { Fiscal balance } \\
\text { (\% of GDP, PPP GDP weighted average) }\end{array}$ & -6.3 & 5.4 & 11.6 \\
\hline $\begin{array}{l}\text { Gross public debt } \\
\text { (\% of GDP, PPP GDP weighted average) }\end{array}$ & 13.2 & 56.8 & 32.1 \\
\hline $\begin{array}{l}\text { Current account balance } \\
\text { ( } \% \text { of GDP, PPP GDP weighted average) }\end{array}$ & 5.1 & -4.8 & 15.8 \\
\hline $\begin{array}{l}\text { Current account balance } \\
\text { (in billions of US dollars) }\end{array}$ & 12.0 & -2.4 & 121.6 \\
\hline $\begin{array}{l}\text { Gross official reserves } \\
\text { (in billions of US dollars) }\end{array}$ & 102.2 & 66.1 & 280.1 \\
\hline Population (millions) & 18.9 & 25.9 & 35.6 \\
\hline
\end{tabular}

(Note) $\mathrm{mbpd}=$ Million Barrells Per Day

(Source) The Macroeconomics of the Arab States of the Gulf (2014). 
Figure A. GCC exports and imports by region

(2013, Measurement in \%)

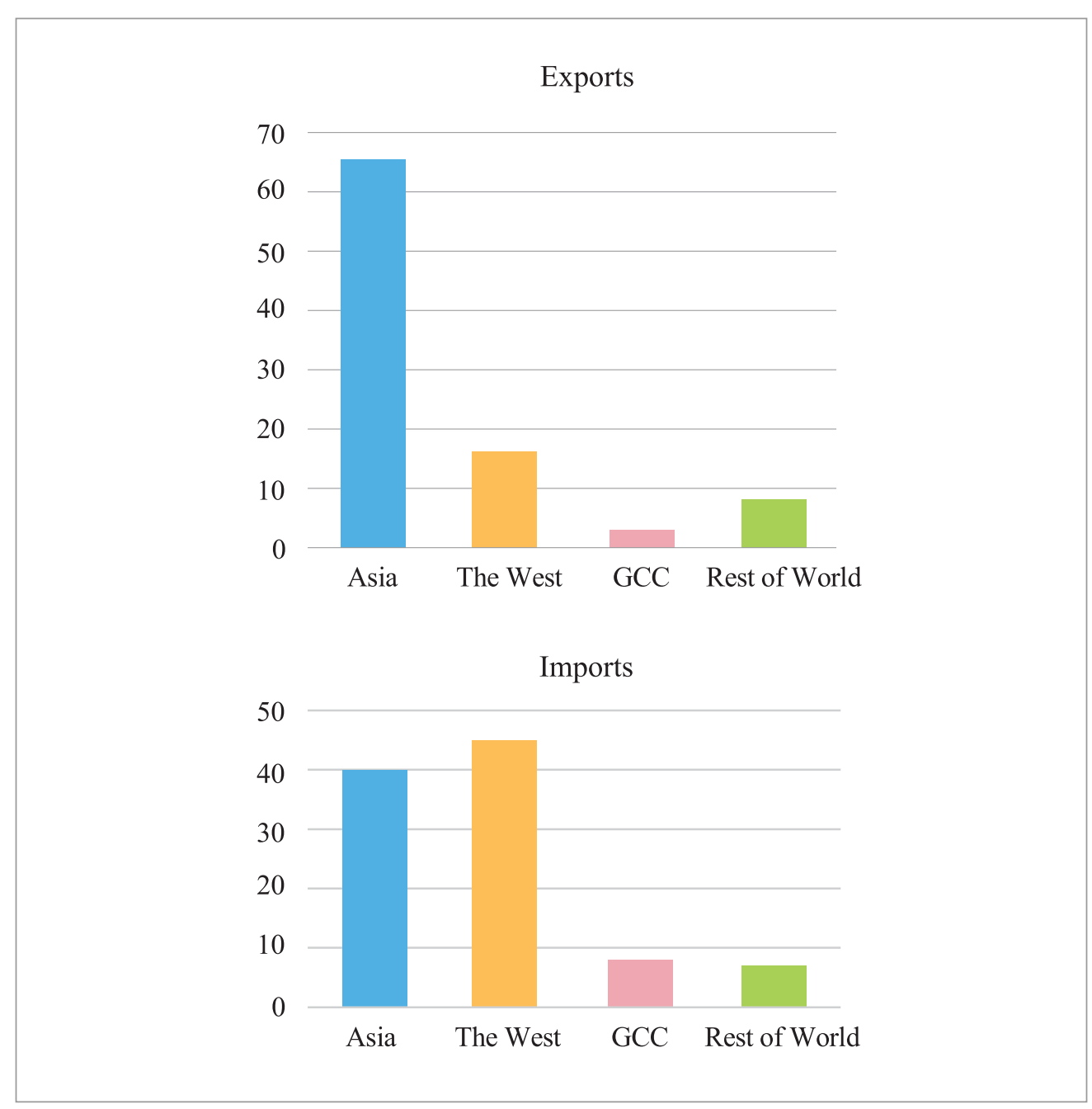

(Source) Author's own construction, data from the IMF Direction of Trade Statistics (2014). 


\section{Figure B. Bahrain Exports to GCC}

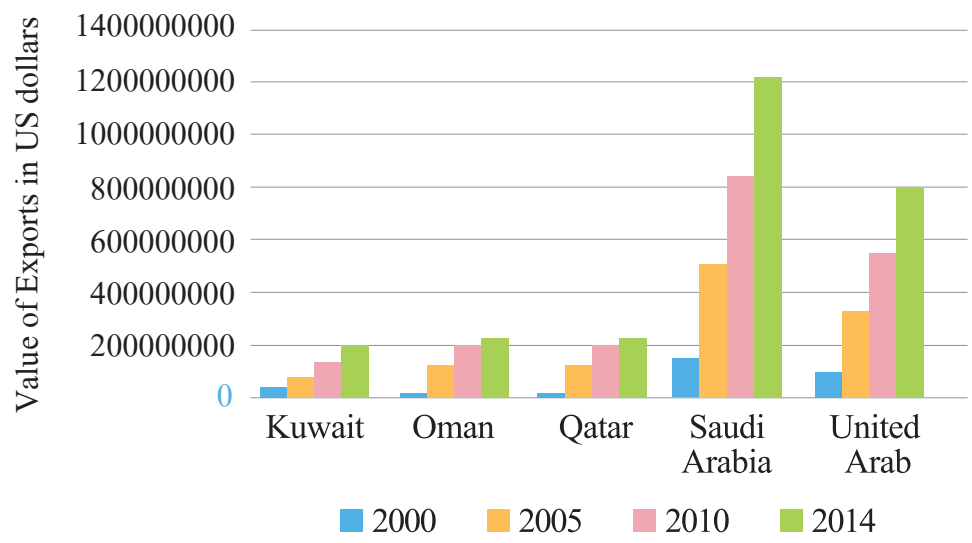

Figure C. UAE Exports to GCC

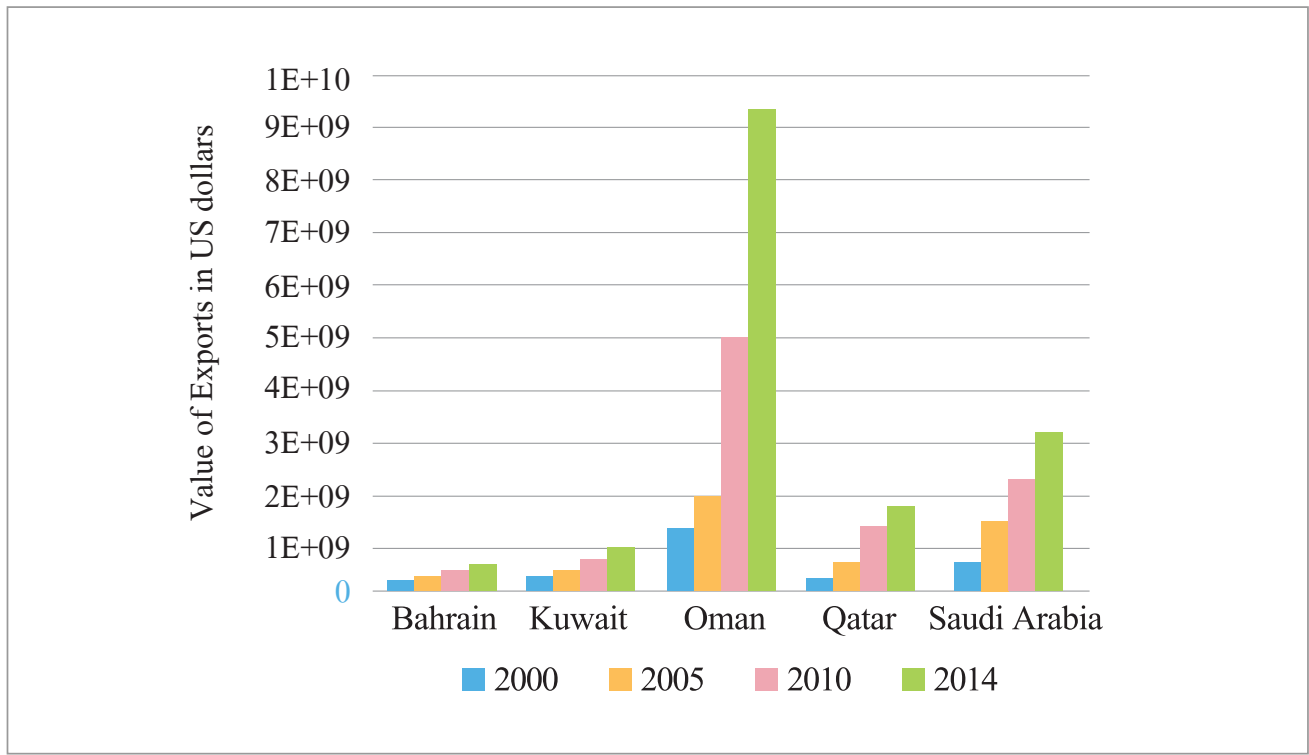

(Source) Author's own construction, data from IMF, Direction of Trade Statistics (2015). 